\title{
Some aspects on improvement of water resistant perfornace of gypsum binders
}

\author{
Ekaterina Fomina $^{1}$, Elena Voitovich ${ }^{1,2, *}$, Oleg Brukhanov ${ }^{2}$ \\ 1 Belgorod State Technological University, Russia \\ ${ }^{2}$ Moscow State University of Civil Engineering, Russia
}

\begin{abstract}
The study reports that control of water resistant and strength performance of composite binder can be accomplished by using nanostructured gypsum silicate binder and portland cement and reduction of calcium sulfate dihydrate. Formation of an arranged more dense packing in crystal matrix of binder structure can be achieved through polydispersity of nanostructured silicon component. Highly reactive silica particles participate in synthesis of microcrystalline compounds such as hydroxylellestadite and serve as nucleation sites providing an increase of surface contact area between crystal structures. Cement in the system provides conditions to synthesis of stable flat-like hydroxysulfoaluminates. Upon hydration of a binder crystals of calcium sulfate dihydrate impound to a mass of water resistant crystalhydrate new formations, type and morphology of which promotes decreasing of intercrystal porosity followed by density, strength and water resistance increase of the composite.
\end{abstract}

\section{Introduction}

Gypsum materials can be attributed to progressive construction materials thought their simplicity, feasibility and low energy demand during production.

Gypsum-based products are usually with a low mass, relatively low thermal and sound conductivity, they can be easily shaped into any architectural configuration of any color [1].

The orientation of modern technologies of construction materials production to nanosystem concept allowed the design principles of highly efficient binder composites to be developed due to application of nanodispersed modifiers [2-5].

The studies related to modification of anhydride composites with ultra- and nanodispersed admixtures were done [6]. As a main binding component and an effective nanostructured modifier can be used nanostructured silica component [7].

Nanostructure silica component (NSC) is a mineral polydispersed system of dominantly silicate composition with high concentration of active solid phase and up to $5-10 \%$ of nanodispersed particles.

NSC is produces using eco-friendly technology based on mechano-chemical synthesis of silica component in wet conditions at high concentration of solid phase, high temperature

\footnotetext{
* Corresponding author: e.voitovich@mail.ru
} 
and a margin dissolution. Polydispersed particle size distribution of NSC have an impact on gypsum binder system at different scale (macro-, micro- and nanoscale).

Microparticles of NSC $(1-100 \mu \mathrm{m})$ act as a microfiller in the composite binder and promote a maximally compact defect-free structure [8].

It was found that nanodispersed particles $(0,02-0,1 \mu \mathrm{m})$ involved to chemical interaction processes with a synthesis of buffer nanosized formations such as calcium sulfosilicates and new formations such as hydroellestadite $[9,10]$.

This helped to reduce portion of gypsum binder in the composite up to $30 \%$ and increase a quality of gypsum composites as well as materials for different application on their base.

Regardless of high strength the obtained binder has a low water resistance, which restricts its outdoor application as well as indoor constructions with a high humidity.

Low water resistance of gypsum binder driven by high solubility of calcium sulfate dihydrate, high permeability and wedge effect of water molecules when penetration into the intercrystalline cavities (Rehbinder effect). This leads to strength reduction and failure of gypsum materials under the water impact $[11,12]$.

Nevertheless, water resistant performance of nanostructured gypsum-silicate binder can be improved by incorporation of an optimal quantity of cement, which due to its hydration will contribute to a synthesis of slow-soluble phases, and cover calcium sulfate dehydrate in the binder structure, protecting it this way of water impact.

\section{Materials and methods}

The development of water resistant gypsum composite was focused on study of the effect of NSC and Portland cement concentration on physical and mechanical performance of gypsum binder according to Russian standard GOST 23789-79 “Gypsum binders. Testing procedure" [13].

Standard beams of $16 \times 4 \times 4 \mathrm{~cm}$ was prepared. Water in the $1 \mathrm{~m}^{3}$ of gypsum mix was adjusted in order to achieve a standard flow.

X-ray diffraction of the specimens was done using diffractometer DRON-4. WorkStation with $\lambda \mathrm{Cu}_{\mathrm{K} \alpha 1,2}$ with Ni-filter attenuation of $\beta$-radiation components.

The full-width at half-maximum (FWHM) of these patterns was $0,05^{\circ}$. The time of intensity measurement of the at the scan point $-1 \mathrm{~s}$.

IR-spectroscopy of aluminosilicate materials and obtained cellular concrete was performed with IR-Fourier spectrometer VERTEX 70/70v.

Porosity was defined using concrete cubes with the size of $7 \times 7 \times 7 \mathrm{~cm}$, after 28 days of storage at natural conditions and drying till a constant mass, according to the Russian standard GOST 12730.4-78 [14].

After the test, all specimens were weighted.

\section{Experimental part}

Nanostructured silica component (NSC) is a mineral silicate polydisperse binder system with high concentration of active solid phase and up to $5-10 \%$ of nanodispersed particles. The binder was produced by wet milling of quartz sand in ball mill.

The main characteristics of the nanostructured silicate binder presented in Table 1. 
Table 1. Main characteristics of nanostructured silicate binder

\begin{tabular}{|c|l|c|c|c|}
\hline № & \multicolumn{1}{|c|}{ Parameters } & Units & Spec. limit & Test result \\
\hline 1 & Compressive strength & $\mathrm{MPa}$ & $\geq 3$ & 4,5 \\
\hline 2 & Flexural strength & $\mathrm{MPa}$ & $\geq 1,5$ & 2,5 \\
\hline 3 & Density & $\mathrm{kg} / \mathrm{m}^{3}$ & $2000-2250$ & 2140 \\
\hline 4 & Dispersity & $\%$ & $\leq 1$ & 0,89 \\
\hline 5 & Viscosity & $\mathrm{Pa}\ulcorner$ & $\leq 25$ & 16,3 \\
\hline 6 & $\mathrm{pH}$ & $\mathrm{pH}$ & $7-10$ & 8 \\
\hline 7 & Water content & $\%$ & $14-20$ & 14,5 \\
\hline 8 & $\begin{array}{l}\text { Specific efficiency of natural } \\
\text { radionuclides }\end{array}$ & $\mathrm{Bq} / \mathrm{kg}$ & 370 & 210 \\
\hline
\end{tabular}

Gypsum binder (GB) without NSC and Portland cement was considered incorporation as a reference specimen. Percentage of NSC and Portland cement varied of 10 to $3 \%$ with pace variability of $10 \%$ and of 1 to $5 \%$ with pace of variability of $2 \%$ respectively.

Table 2.Relation of physical-and-chemical characteristics of composite binder vs. concentration of NSC and Portland cement

\begin{tabular}{|c|c|c|c|c|c|c|c|c|}
\hline \multirow{3}{*}{ № } & \multicolumn{3}{|c|}{ Composition, $\%$} & \multirow{2}{*}{\multicolumn{2}{|c|}{ Setting time, sec. }} & \multirow{3}{*}{$\begin{array}{l}\text { Compressive } \\
\text { strength, } \\
\text { after } 28 \text { days, } \\
\text { MPa }\end{array}$} & \multirow{3}{*}{$\begin{array}{c}\text { Density, } \\
\mathrm{kg} / \mathrm{m}^{3}\end{array}$} & \multirow{3}{*}{$\begin{array}{l}\text { Malaxation } \\
\text { coefficient }\end{array}$} \\
\hline & \multirow{2}{*}{$\begin{array}{l}\text { G } \\
B\end{array}$} & \multirow{2}{*}{ NSC } & \multirow{2}{*}{$\mathrm{PC}$} & & & & & \\
\hline & & & & Initial & Final & & & \\
\hline 1 & $\begin{array}{c}10 \\
0\end{array}$ & - & - & 535 & 985 & 10,19 & 1201,1 & 0,46 \\
\hline 2 & 90 & 10 & - & 566 & 1082 & 11,88 & 1263,2 & 0,50 \\
\hline 3 & 80 & 20 & - & 805 & 1330 & 13,97 & 1307,5 & 0,54 \\
\hline 4 & 70 & 30 & - & 1025 & 1634 & 9,46 & 1274,3 & 0,56 \\
\hline 5 & 89 & 10 & 1 & 571 & 1089 & 11,62 & 1324,5 & 0,55 \\
\hline 6 & 19 & 20 & 1 & 825 & 1344 & 13,76 & 1330,2 & 0,59 \\
\hline 7 & 69 & 30 & 1 & 1036 & 1628 & 9,89 & 1334,9 & 0,61 \\
\hline 8 & 87 & 10 & 3 & 554 & 1102 & 12,45 & 1278,2 & 0,59 \\
\hline 9 & 77 & 20 & 3 & 835 & 1372 & 15,16 & 1332,5 & 0,64 \\
\hline 10 & 67 & 30 & 3 & 1039 & 1701 & 12,26 & 1337,3 & 0,68 \\
\hline 11 & 85 & 10 & 5 & 536 & 1054 & 13,54 & 1298,1 & 0,65 \\
\hline 12 & 75 & 20 & 5 & 834 & 1354 & 16,48 & 1342,4 & 0,70 \\
\hline 13 & 65 & 30 & 5 & 1103 & 1704 & 15,73 & 1351,1 & 0,72 \\
\hline
\end{tabular}

Replacement of $10 \%$ gypsum binder by NSC (mix 2, Table 2) impacted the rate of hydration followed by retardation of setting time of the composite. Further change in hydration was observed with additional incorporation of $1 \%$ of PC (mix 5, Table 2 ). In this case, initial setting time was retarded to $7 \%$, and final setting time to $11 \%$.

The results of physical and mechanical tests showed, reduction in gypsum content by incorporation of highly dispersed hydraulic admixture NSC and PC provides a better density of the composite from $1201 \mathrm{~kg} / \mathrm{m}^{3}$ to $1351 \mathrm{~kg} / \mathrm{m}^{3}$.

At the same time an improvement of water resistance of the composite was observed, where the maximal malaxation coefficient was 0,72 for mix 13 (Table 2), which is 1,5 times higher than that for reference specimens. The best specimens were obtained by replacing of $20-30 \% \mathrm{NSC}$ and 5\% PC (mixes 12 and 13, Table 2). The strength was increase up to $55-60 \%$ and malaxation coefficient was $0,70-0,72$. 
Malaxation coefficient describe water resistance of composite, that can be defined though water absorption, whereas, water absorption related to porosity and structure of material. In this regard, an analysis of an open porosity based on kinetics of water saturation (discrete method) was performed. Results of the calculations presented in Table 3.

Table 3.Porosity of gypsum systems vs. composition

\begin{tabular}{|c|c|c|c|c|c|c|}
\hline \multirow{2}{*}{$\begin{array}{l}\text { Mix ID } \\
\text { (accordi } \\
\text { ng to } \\
\text { Table 2) }\end{array}$} & \multirow{2}{*}{$\begin{array}{c}\text { Total } \\
\text { porosity } \\
\mathrm{cm}^{3} / \mathrm{g}\end{array}$} & \multicolumn{4}{|c|}{ Pore distribution by radius, $\%$} & \multirow{2}{*}{$\begin{array}{l}\text { Volume of } \\
\text { pores with } \mathrm{R} \\
\text { less than } 94,6 \\
\mathrm{~nm}, \mathrm{~cm}^{3} / \mathrm{g}\end{array}$} \\
\hline & & $\begin{array}{c}<0,01 \\
\mu \mathrm{m}\end{array}$ & $0,01-0,1 \mu \mathrm{m}$ & $\begin{array}{c}0,1-1 \\
\mu \mathrm{m}\end{array}$ & $\begin{array}{l}>1 \\
\mu \mathrm{m}\end{array}$ & \\
\hline 1 & 0,3065 & 0,6 & 16,6 & 27,5 & 55,3 & 0,02 \\
\hline 4 & 0,2071 & 17,6 & 36,4 & 30,6 & 15,4 & 0,04 \\
\hline 13 & 0,1798 & 20,2 & 41,3 & 26,8 & 11,7 & 0,04 \\
\hline
\end{tabular}

Based on the data, structure of gypsum stone for reference specimen is macroporous with dominate pore radius $>1 \mu \mathrm{m}$. The amount of pores with radius $<0,01 \mu \mathrm{m}$ is extremely low (mix 1, Table 3). Shift from macroporosity towards mezoporosity in the binder system 'GB-NSC-PC' was observed.

Pore space structure of nanostructured gypsum silicate binder with cement can be characterized as microcrystalline with prevalence of pores with radius $0,01-0,1 \mu \mathrm{m}$ (about $40 \%$ ) and with radius $<0,01 \mu \mathrm{m}$ (about $20 \%$ ). This caused by formation of more dense crystal packing as well as by shifting microporosity towards nanoporosity, which results in improvement of water resistance of composite.

Study of phase composition of the binder with incorporation of cement onto nanostructured gypsum silicate binder was performed with analysis of X-ray diffraction of the specimens.

Considering the fact that main formulation of the composite was presented by gypsum and NSC, the most intensive X-day diffraction peaks belong to those components. For identification of new formations a quantitative full-prof XRD using Rietveld refinement method was carried out.

As structural models for mineral components were used: gypsum $\mathrm{CaSO}_{4} \cdot 2 \mathrm{H}_{2} \mathrm{O}$, bassanite $\mathrm{CaSO}_{4} \cdot 0,5 \mathrm{H}_{2} \mathrm{O}, \alpha$-quartz $\mathrm{SiO}_{2}$, anhydride $\mathrm{CaSO}_{4}$, dolomite $\mathrm{CaMg}\left(\mathrm{CO}_{3}\right)_{2}$, hydroxylellestadite $\mathrm{Ca}_{5}\left(\mathrm{SiO}_{4}\right)_{3}\left(\mathrm{SO}_{4}\right)_{3}(\mathrm{OH})_{2}$, calcium hydroxysulfoaluminate $3 \mathrm{CaO} \cdot \mathrm{Al}_{2} \mathrm{O}_{3} \cdot \mathrm{CaSO}_{4} \cdot 12 \mathrm{H}_{2} \mathrm{O}$.

Based on the obtained data, the entire hydrated system comprises interaction products of gypsum and NSC in the form of hydroxylellestadite and the interaction produts of portland cement and gypsum in the form of calcium hydroxysulfoaluminate (Fig. 1 b, c). Due to low content of portland cement (up to 5\%), a small amount of calcium hydroxide is formed in the binder system, which is just enough for binding of calcium hydroxysulfoaluminate into steady low sulfate phase.

Based on IR-spectroscopy analysis, the absorption band at $900-1000 \mathrm{~cm}^{-1}$ confirms a presence of calcium hydroxysulfoaluminate in the system (Fig. 2). Variation in intensity fluctuation and some frequency shift at the range of $1100-1400 \mathrm{~cm}^{-1}$ also validate a crystal structure rearrangement of hydrate phases with the participation of ion SO. Taking into account, that deformation fluctuations of adsorbed water molecules take place in the interval of $1600-1700 \mathrm{~cm}^{-1}$, it is possible, that the cement portion takes part in building-up of crystalhydrate new formations. 


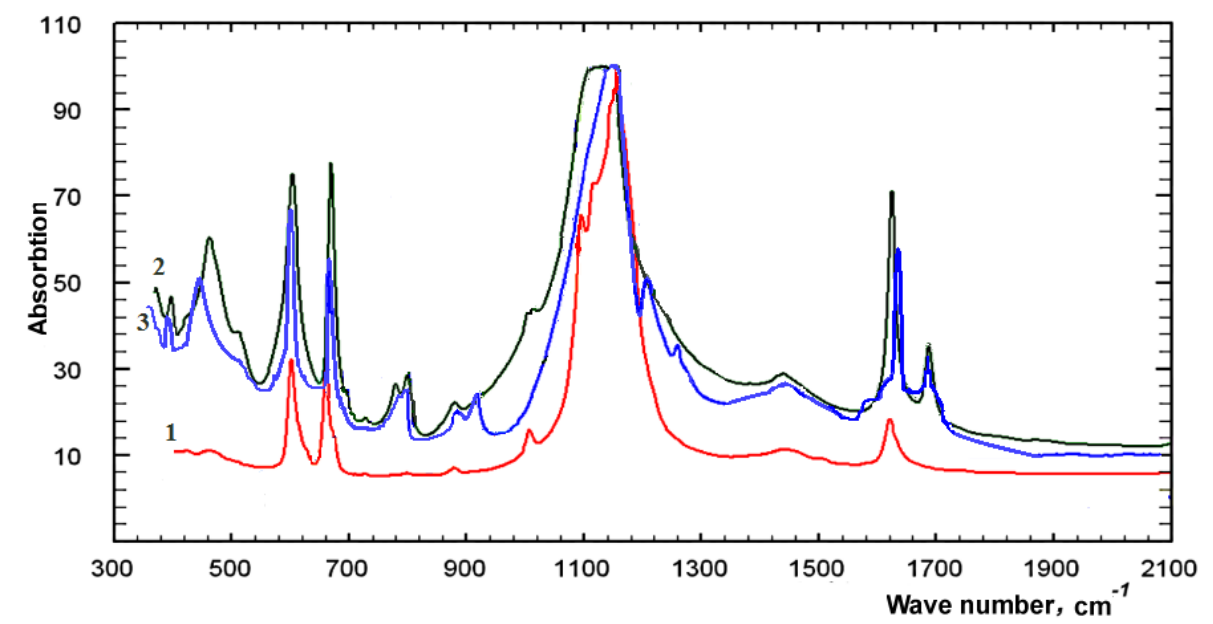

Fig. 2. IR-spectrum for: 1 - mix № 1; 2 - mix № 4; 3 - mix № 14 (see Table 2).

Comparing the IR-spectroscopy and XRD results, it can be concluded that reduction in gypsum content as well as the presence of NSC and optimal portion of portland cement in combination make it possible to synthesis of slow-soluble phases of hydroxylellestadite $\mathrm{Ca}_{5}\left(\mathrm{SiO}_{4}\right)_{3}\left(\mathrm{SO}_{4}\right)_{3}(\mathrm{OH})_{2}$, as well as the phases of hydroxysulfoaluminates such as $3 \mathrm{CaO} \cdot \mathrm{Al}_{2} \mathrm{O}_{3} \cdot \mathrm{CaSO}_{4} \cdot 12 \mathrm{H}_{2} \mathrm{O}$, which boost water resistance of the binder. SEM analysis of the reference composition demonstrated, that its structure comprises bigger defected gypsum crystals with a few intergrowth contact points (Fig. 3, a). Formation of bigger crystals leads to porosity increase, which is $0,31 \mathrm{~cm} / \mathrm{g}^{3}$ for reference composition (Table 3 ).

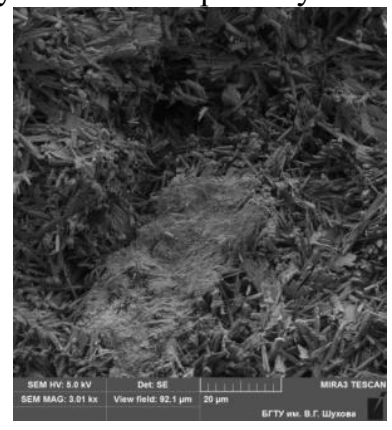

a

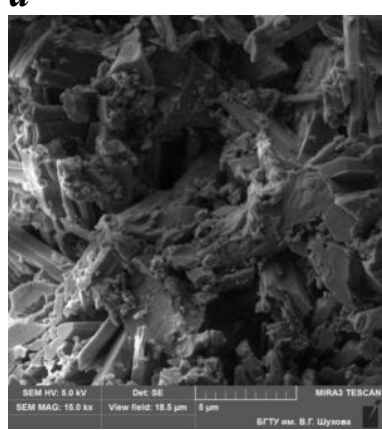

$a$

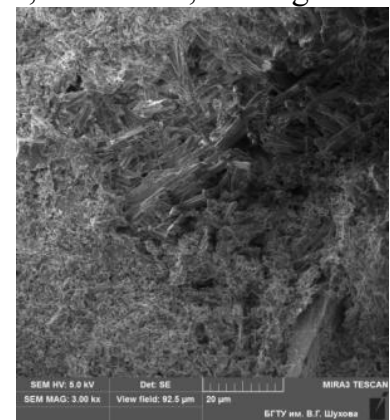

b

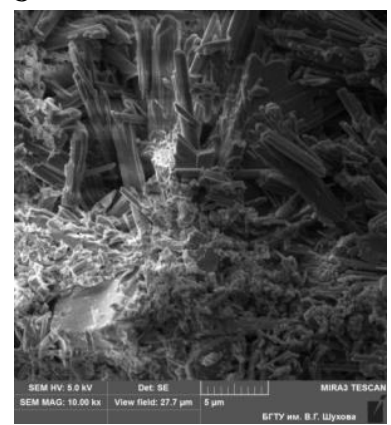

b

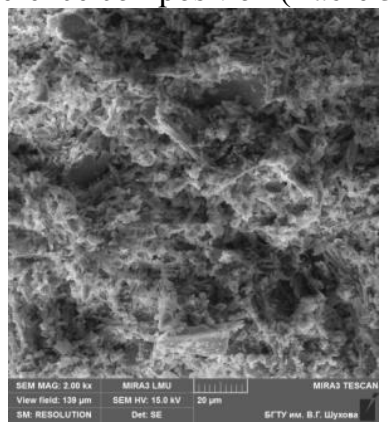

c

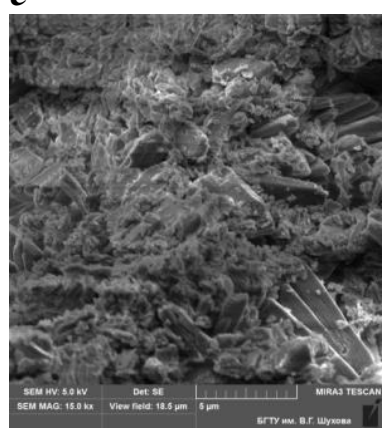

$c$

Figure 3. SEM images of gypsum composites:

$\mathrm{a}-\operatorname{mix}$ № 1, b - mix № 4, c - mix № 14 (see Table 2) 
Incorporation of NSC with finely-crystalline structure helps to densify packing of grains in crystal matrix. Moreover, NSC particles serve as nucleation sites, providing an increase of contact area between crystal structures and finely-crystalline new formations such as hydroxylellestadite (Fig. 1, b). In contrast to reference specimen, porosity of the composite dropped to $0,21 \mathrm{~cm} / \mathrm{g}^{3}$, at the same time, the density was increased up to $1274 \mathrm{~kg} / \mathrm{m}^{3}$, which boosts strength and water resistance of developed compositions.

Incorporation of portland cement creates a favorable conditions for additional formation of hydrates in form of flake-like aggregates - hydroxysulfoaluminates (Fig. 1, c). It is known, that low water resistance of gypsum binder driven by high solubility, high permeability of calcium sulfate dihydrate and by wedge effect of water molecules when penetration into the intercrystalline cavities (Rehbinder effect) [15]. This leads to strength reduction and consequent failure of gypsum materials under the water impact.

The developed binder compositions with reduced amount of gypsum, showed, that the structure framework of calcium sulfate dihydrate becomes overgrown by new formations synthesized due to interaction of the system 'GB-NSC-PC', which provide an improvement in density of crystal matrix from 1201 to $1351 \mathrm{~cm} / \mathrm{g}^{3}$, increase strength up to $61 \%$, reach a malaxation coefficient up to $0,70-0,72$ with consequent improvement in water resistance of the composite.

\section{Key insight}

It was found out, that its possible to control of gypsum binder performance by engineering of multicomponent binder and modification of conditions for phase- and structure formation. It was determined in this study, that water resistance and strength performance can be adjusted by incorporating nanostructured gypsum silicate binder and portland cement with reducing amount of calcium sulfate dihydrate.

Use of finely-crystalline NSC provide a better packing density of grains in crystal matrix of binder. For the system 'GB-NSC-PC' macroporosity range was shifted towards mesoporosity with formation of high dense impermeable structure.

Hydration of gypsum binder in presence NSC and PC was found to slow down. With reduction of gypsum portion in the hydrated system less soluble new formations such as hydroxylellestadite $\mathrm{Ca}_{5}\left(\mathrm{SiO}_{4}\right)_{3}\left(\mathrm{SO}_{4}\right)_{3}(\mathrm{OH})_{2}$ and calcium hydroxysulfoaluminate $3 \mathrm{CaO} \cdot \mathrm{Al}_{2} \mathrm{O}_{3} \cdot \mathrm{CaSO}_{4} \cdot 12 \mathrm{H}_{2} \mathrm{O}$, in comparison with calcium sulfate dihydrate, were observed. The presence of such phases in the system boost water resistance of the binder.

Composition optimization of gypsum binder using NSC and portland cement allows changing the phase- and structure formation kinetics followed by increase in matrix dense of the harden binder and by boost of water resistance and strength of the composite.

\section{Conclusion}

Improvement in water resistance of gypsum binder can be achieved by varying of phase formation with at simultaneous reduction of gypsum binder portion up to $35 \%$ by replacing it with NSC and portland cement. Then, the hardening process goes without significant fluctuations in hydration kinetics and destructive deformations. High disperse NSC promote more arranged and dense structure and participate in a synthesis of finely-crystalline phases such as hydroxylellestadite.

The presence of cement in the system contributes to additional synthesis of steady flakelike hydroxysulfoaluminates. As a result, the crystals of calcium sulfate dihydrate inclosed into the mass of water resistant crystalhydrates, the morphology of which determine intercrystal porosity, providing an improvement in dense to $12,5 \%$, strength to $61 \%$, 
malaxation coefficient of $0,70-0,72$ and as a consequence increases water resistance of the composite. The developed binder meets the requirement for its application in construction materials for external walling.

Work is performed under the strategic development program BSTU. V.G. Shoukhov.

\section{References}

1. A.V. Volzhensky, V.I. Stambulko, A.V., Stroyizdat, 316 (1971)

2. Yu.M. Bazhenov, V.S. Demyanova, V.I. Kalashnikov, Assosiations of construction High Establishments, 368 (2006)

3. A.V. Cherevatova, E.O. Gashchenko, Bulletin of Belgorod St. Technological University named after V. G. Shoukhov 1, 25-30 (2007)

4. V.S. Lesovik, V.V. Potapov, N.I. Alfimova, O.V. Ivashova, Construction materials 12, 60-62 (2011)

5. N.I. Kozhukhova, E.V. Voitovich, A.V. Cherevatova, I.V. Zhernovsky, D.A. Alehin, Construction materials 6, 65-69 (2015)

6. I.S. Maeva, Abstract of a PhD thesis, 154 (2010)

7. I.V. Zhernovsky, V.V. Strokova, A.V. Cherevatova, LAM LAMBERT Academic Publishing GmbH \& Co. KG, 170 (2011)

8. E.V. Voitovich, A.V. Cherevatova, I.V. Zhernovsky, H.B. Fisher, K. Sobolev, Journal of the Society for American Music 2, 1611 (2014)

9. I.V. Zhernovsky, A.V. Cherevatova, E.V. Voitovich, N.I. Kozhukhova, E.I. Evtushenko, International Journal of Applied Engineering Research 11(12), 7732-7735 (2016)

10. V.V. Strokova, A.V. Cherevatova, I.V. Zhernovsky, E.V. Voytovich, Construction materials 7, 9-12 (2012)

11. V.V. Babkov, V.M. Latyipov, L.N. Lomakina, V.S. Asyanova, R.I. Shigapov, Construction materials 7, 4 (2012)

12. V.S. Lesovik, N.V. Chernyisheva, V.G. Klimenko, News of Higher Educational Institutions 4, 3-11 (2012)

13. Russian standard 23789-79 «Gypsum binders. Test methods»

14. Russian standard 12730.4-78 «Concretes. Methods of determination of porosity parameters»

15. A.V. Ferronskaya, ACB, 488 (2004) 